\title{
Correlation Between Mastery of Concepts and Argumentation Skills of High School Students
}

\author{
$1^{\text {st }}$ Merta Simbolon* \\ Department of Physics Education \\ Universitas Musamus \\ Merauke, Indonesia \\ simbolon_fkip@unmus.ac.id
}

\author{
$2^{\text {st }}$ Anderias Henukh \\ Department of Physics Education \\ Universitas Musamus \\ Merauke, Indonesia \\ henukh_fkip@unmus.ac.id
}

\author{
$3^{\text {st }}$ Rikardus Feribertus Nikat \\ Department of Physics Education \\ Universitas Musamus \\ Merauke, Indonesia \\ nikat_fkip@unmus.ac.id
}

\begin{abstract}
This research aims to determine the correlation between mastery of concepts and student argumentation skills. The sample used in this study was students grade one senior high school of one of the high schools in Bandung. Total sample used are 30 students. Class random technique is used to obtain research samples. This research uses descriptive quantitative method. The data was obtained by giving a concept mastery test instrument that consist of 10 multiple choice questions and an instrument of students' argumentation skills based on Toulmin framework that consist of 10 essay questions. In addition, interviews were also conducted with teachers and students to get supporting data. To find out the correlation between mastery of concepts and students' argumentation skills, the Spearman Correlation Test was used. The results of this study indicate that there is a strong correlation between students' mastery of concepts and argumentation skills with a correlation value of 0.70 .
\end{abstract} skills

Keywords: correlation, mastery of concepts, argumentation

\section{INTRODUCTION}

Education carried out has a role so that the potential that is embedded in students can develop properly. The implementation of education is the responsibility of the teacher [1]. In practice in the field, teachers must be able to improve the main aspects of students ranging from affective, cognitive, to psychomotor. The main competencies in this learning have different aspects of assessment. Knowledge aspects can be assessed from the activities of remembering, understanding, applying, evaluating, and creating. The aspects of skills are assessed through adjusting, training, encouraging, and shaping activities. Attitude aspects can be assessed from the activities of following, obeying, helping, completing, and influencing.

Temperature and heat are physics subject matter which is considered by students to be very difficult and boring. This was proven by researchers through interviews with students in one of Bandung's high schools. The results of students' mastery of concept tests also showed low results. Many students claim that physics is a difficult and boring subject. Students consider physics subject difficult because physics is a discipline that uses varied understanding methods, translates a sentence into another sentence, translates tables, graphs, equations, diagrams, and maps. In addition to strong basic concepts, physics is also a lesson that requires mathematical calculations to solve problems [2]. Whereas teachers as educators should be able to understand how children learn so that the learning process takes place effectively [3]. The research conducted by Hastuti identified several errors made by students when working on temperature and heat matter problems, namely: the use of inaccurate concepts, the use of data in the problem, the selection of the wrong strategy, improper systematics, calculations using equations, and some of the questions did not get response from students. These mistakes are description of how to master students' concepts. Mastery of concepts is the main point in improving students' mastery of concepts.

Mastery is an ability to explain a concept using one's own language and is different from the sentences in the textbook [4]. The ability of students to construct their concept is different [5]. The concept is part of cognitive which can simplify the information received during the learning process. Therefore, mastery of concepts in physics can be interpreted as the ability of students' scientific understanding of the physics materials that are studied in order to be applied in student life.

In this study, the mastery of concepts assessed is related to the material temperature and heat, both understanding and applying them in life. The assessment used is based on Anderson's cognitive aspects which are limited to aspects of remembering, understanding, applying, and analyzing [6]. Indicators used in the assessment of concept mastery are also adjusted to the six levels in Bloom's cognitive domain in the learning process, namely: (1) knowledge that is linked to student assessments in remembering information that students have previously obtained in class, (2) understanding related by assessing the ability of students to relate concepts that are already known to use their own sentences, (3) applying the assessment of students' abilities in applying information and knowledge that has been received when discovering new circumstances, (4) analyzing including solving, affirming, and linking various facts and assumptions as well as being able to check whether there are discrepancies in the concept, (5) synthesizing that is able to connect several elements of knowledge received so as to form a complete pattern of knowledge, and (6) evaluating is the highest level that serves to produce decisions based on arkan value for opinions, methods, and products that have been formed. 
The renewal of the curriculum by the government is certainly one of the efforts aimed at improving students' abilities in learning, especially cognitive and psychomotor. But the reality on the ground shows that the level of mastery of student concepts in physics is still relatively low. This was revealed in a study conducted by Siswanto that the concept mastery test for temperature and heat material showed that the average student achievement for the ability to remember was $50 \%$, the ability to understand by $40 \%$, the ability to apply by $25 \%$, and the ability to analyze by $10 \%$ of the maximum average that should be achieved is $100 \%$ [7].

Mastery of concepts in physics is considered very important because in addition to improving students' cognitive, aspects of knowledge are also related to improving aspects of skills. One aspect of the skills needed in learning is scientific argumentation skills. The ability to argue will be able to improve the verbal and reasoning of students. The basic word of argument is "argument" and can be interpreted as an opinion expressed by someone and equipped with certain facts to support the data [8].

The scientific argument that is expressed naturally requires scientific reasoning as well. This scientific reasoning serves to instill scientific concepts for students. When students already have a good mastery of concepts, students will be more confident in expressing scientific arguments. Scientific arguments presented by students must also be assessed for quality. This quality assessment can be based on Toulmin's argumentation model which includes Claims, Data, Justification, Support, and Disclaimer [9].

This argumentation skill is expected to be a bridge for students to better understand a concept learned. Research on argumentation skills has been done by many researchers before. Some of them are Siswanto [7], Muslims [10], and Huda [11]. However, research is limited to improving cognitive domains for competence in understanding and increasing the realm of argumentation skills for the realm of claiming, data, justification, and support. Research on how strong the correlation between mastery of concepts and student argumentation skills has not been done specifically in the field of physics so researchers examined how strong the correlation between both

\section{RESEARCH METHODS}

This study uses a random class technique in selecting samples [12]. A total of 30 high school students of a high school in Bandung were involved in this study. The data needed was taken using instrument of mastery of concepts and student argumentation skills. In addition to using essay test instruments, the teacher teaching physics and students at the school also conducted interviews to obtain data that supports the test results. The interview is useful to find out what factors cause students to incorrectly answer the test questions given. The type of error is determined by looking at the highest percentage of students who answer incorrectly on each test item. The percentage of students 'mistakes in answering questions was analyzed and used to see the students' concept mastery profile.

The data collected using 10 questions of multiple choice and 10 questions of essay tests. The steps used in compiling the test, namely: (1) choosing the specific material desired, (2) determining the lattice of questions, (3) compiling questions, (4) conducting the analysis process, (5) consulting the questions to experts, and (6) revising the questions. The validity of the content is needed to assess the question instrument and the one who does it is an expert, in this case the lecturer. This study combines data from test results and interview results. Data analysis techniques include three steps, namely: Data recapitulation, data analysis and the results of the analysis can be drawn conclusions.

\section{RESUltS AND DisCUSSION}

\section{A. Mastery of Student Concepts}

From the results of the tests carried out, obtained varied student answers. The following data and discussion of the results of students' concept mastery tests.

Problem number 1 shows that $80 \%$ of students answered that there was a temperature transfer from the floor to ice and some answered that there was a temperature transfer from ice to the floor. The large percentage that states this answer shows that there is not yet a good understanding of basic concepts in students, especially understanding of the difference in temperature and heat. Problem number 2 shows that $85 \%$ of students answer that ice is melting because of the principle of Black, low temperature rises to high, high temperature drops to low. From this answer it can be concluded that students only know the concepts but do not understand their meaning so they cannot relate them to the application of physical phenomena in daily life.

Problem number 3 shows that $30 \%$ of students answered air and $50 \%$ of students answered water vapor. In this problem, although some still do not understand the concept of evaporation, but some students have been able to distinguish air and water vapor. Problem number 4 shows that $50 \%$ of students answer to know the body temperature must be lisa and partly answer because the thermometer is a temperature measuring device. From this student's answer, it can be seen that most students only memorize concepts without understanding them so that they are unable to apply them in their lives.

Problem number 5 shows that $60 \%$ of students answered Iron, glass, aluminum, ice, Water. This answer shows the level of student knowledge about the heat of the type of object is good enough. Problem number 6 shows that $90 \%$ of students answer 46,60C. In the calculation of fundamental unit conversions in the concept of temperature and heat students are still weak. This answer shows students do not understand how to convert between units.

Problem number 7 shows that $60 \%$ of students answer that water will still boil with the same temperature of $1000 \mathrm{C}$. This student answer error shows a lack of understanding of the concept of boiling water at different air pressures. Problem number 8 shows that $87 \%$ of students answered correctly that iron absorbs heat faster than Kim's hands. Problem number 9 shows that $70 \%$ of students answered correctly and showed understanding and were able to distinguish the concepts of release and absorption of heat. Problem number 10 shows that $85 \%$ of students answer to keep the body warm. This answer shows that students' understanding of the application of physics concepts is still lacking. 


\section{B. Students'Argumentation Skills}

The argumentation skills that will be assessed in this study are directed according to the Toulmin framework. Each argument is entered in accordance with existing indicators for further analysis. The results of the acquisition of students' argument scores are presented in Table 1.

TABLE I. PERCENTAge of ARGUMENTATION SKILlS ACHIEVEMENT OF EACH INDICATOR

\begin{tabular}{|c|c|}
\hline $\begin{array}{c}\text { Indicator of Students' } \\
\text { Argumentation Skills }\end{array}$ & $\begin{array}{c}\text { Percentage of } \\
\text { Achievement }\end{array}$ \\
\hline claim & $40 \%$ of ideal score \\
\hline data & $45 \%$ of ideal score \\
\hline warrant & $30 \%$ of ideal score \\
\hline backing & $30 \%$ of ideal score \\
\hline rebbutal & $20 \%$ of ideal score \\
\hline
\end{tabular}

Table 1 shows the acquisition of the smallest percentage results is a refutation indicator. From the results obtained, it can be seen that the concept of physics cannot be used correctly by students to rebut a given problem. The highest score is obtained on the data provision indicator. This means that students know enough about the data needed for the problem but are less able to use it in giving a rebuttal, support, or refutation of the problem presented.

\section{The Correlation Between Concept Mastery And Argumentation Skills}

The analysis of the correlation between mastery of concept and argumentation skill was carried out using nonparametric statistical correlation test for the data of argumentation skills and students' mastery of concepts. Spearman correlation test was used in this study to determine the correlation between the two while the data processing was processed using the ANATEST data processor.

The results of statistical tests conducted obtained a correlation value of 0.70 and a significance level of 0.000 . From these results it can be seen that the significance level is less than 0.050. This means that with a confidence level of $95 \%$ the results of the mastery of the concept can be concluded significantly related to argumentation skills. The magnitude of the correlation between the mastery of concepts with argumentation skills shows how important it is that students master the concepts of physics in order to be able to improve their psychomotor abilities in scientific argumentation.

The results of interviews conducted with students show that students feel more confident to express their arguments if they have understood the concepts of the material being taught. The interview with the teacher also states that students who have higher cognitive abilities are usually able to give arguments better than students who have low cognitive abilities.

The concept is needed in argumentation, because the formation of claims and the submission of reasons which include data, justification, and support, must be based on a good concept. Good mastery of concepts will be in line with the quality of the arguments submitted at each stage. This result is in accordance with Toulmin's opinion about the argument that states that the basis for filing a claim in argumentation must provide the right and reasonable reason according to the correct physics concept because the claim contains principles, explanations, and answers to various problems raised by providing data- supporting data for these reasons [9]. Claims that are accompanied by scientific data submitted will strongly support the acceptance or even rejection of an issue [13]. In addition, the argumentation skill is a skill that is based on an effort so that claims on a problem can be validated.

Squire stated in his findings that a good understanding of the concept would be able to improve and enhance students' argumentation skills [14]. Students' reasoning abilities will certainly be better if they are able to interpret concepts well. This result is also appropriate because the arguments that are taught to students are arguments that emphasize mastery of concepts. In line with this, increased argumentation skills can further strengthen the mastery of student concepts. Therefore, the argumentation activities make the concepts of students become more mature. This finding is in line with what Akarsu stated that the ability to deliver scientific arguments will be able to make students' mastery of concepts stronger [15]. In addition, these findings are also in line with the previous findings presented by Duschl [16], Zohar \& Nemet [17], and Trent [18]. For learning to be successful, education implementation must be designed to increase all potentials within students [19]. Learning systems will be successful for students if appropriate methods are used in learning [20].

\section{CONCLUSION}

From the research and data analysis, it can be concluded that mastery of concepts is strongly related to argumentation skills. If students' mastery of concepts is good, students become more skilled in argumentation and the quality of the arguments delivered is also getting better. Through argumentation activities will also make the concepts embedded in students become even stronger.

\section{ACKNOWLEDGMENT}

Thank you to Universitas Musamus for facilities, supports, and publications. Thank you to SMA Pasundan 2 Bandung for helping us to collect research data.

\section{REFERENCES}

[1] S. Bahri, M. Rahayu, M. Arsyad, S. Supriyadi, K. Arafah, and R. S. Waremra, "Implementation of Basic Physics I ComputerBased Teaching Material on Physics Education Students of Masamus University Animation Teaching Material of Basic Physics I," vol. 1, no. Icst, pp. 1116-1119, 2019, doi: 10.2991/icst-18.2018.225

[2] Ornek, F., "What Makes Physics Difficult?," Int. J. Environ. Sci. Edication, vol. 3, pp. 30-34, 2008

[3] D. R. Suryani, L. W. Nengsih, M. Sianturi, K. D. Nur 'Aini, and E. Meirista, "An Analysis of Grade IV's Error on Whole Number based on Newman Procedure's Cognitive Style," vol. 1, no. Icst, pp. 849-852, 2019, doi: 10.2991/icst-18.2018.172.

Baharuddin, "Peranan Kemampuan Dasar Intelektual Sikap dan Pemahaman dalam Fisika terhadap Kemampuan Siswa di Sulawesi Selatan Membangun Model Mental," Universitas Pendidikan Indonesia, 1982

[5] M. Simbolon, P. Sinaga, and S. Utari, "Effect of Application of Physics Learning material Using Multimode representation to Improve Problem Solving Ability," vol. 57, no. ICMSEd 2016, pp. 150-153, 2017, doi: 10.2991/icmsed-16.2017.33.

[6] L. W. \& D. R. K. Anderson, Kerangka Landasan untuk 
Pembelajaran, Pengajaran dan Asessment. Yogyakarta: Pustaka Belajar, 2001.

[7] Siswanto, I. Kaniawati, and A. Suhandi, "Penerapan Model Pembelajaran Pembangkit Argumen Menggunakan Metode Saintifik untuk Meningkatkan Kemampuan Kognitif dan Keteramplan Berargumentasi Ilmiah," J. Pendidik. Fis. Indones., vol. 10, no. 2, pp. 104-116, 2014, doi: 10.15294/jpfi.v10i2.3347.

[8] J. Siahaan, "Pengaruh Kemampuan Argumentasi Menggunakan Model Pembelajaran Problem Based Learning (PBL) Terhadap Hasil Belajar Geografi Siswa," Universitas Lampung, 2019.

[9] S. Toulmin, The Uses of Argument. New York: Cambridge University Press, 2003.

[10] A. Muslim, \& Suhandi, "Pengembangan Perangkat Pembelajaran Fisika Sekolah untuk Meningkatkan Kemampuan kognitif dan Keterampilan Berargumentasi,” J. Pendidik. Fis. Indones., vol. 8, pp. 174-184, 2012.

[11] F. Huda, "Pengaruh Penerapan Model Pembelajaran Pembangkit Argumen dengan Metode Investigasi Sains terhadap Peningkatkan Kemampuan Argumentasi Siswa Pada Materi Fluida," Universitas Pendidikan Indonesia, 2014.

[12] Sugiyono, Statistika untuk Penelitian. Bandung: Alfabeta, 2009.

[13] J. Osborne, et al "Enhancing The Quality of Argumentation in School Science. Journal of Research in Science Teaching.," $J$. Res. Sci. Teach., vol. 4, no. 10, pp. 994-1020, 2004.

[14] K. Squire, "Developing Scientific Argumentation Skills with a Place-based Augmented Reality Game on Handheld Computers," J. Sci. Educ. Technol., vol. 16, no. 1, pp. 5-29, 2007.

[15] B. Akarsu, "Understanding Elementary Students' Argumentation Skills through Discrepant Event "Marbles in the Jar.," Int. J. Sci. Res. Educ., vol. 6, pp. 221-232, 2013.

[16] R. Duschl, "Science Education in Three-Part Harmony: Balancing Conceptual, Epistemic, and Social Learning Goals.," Rev. Reasearch Educ., vol. 32, pp. 268-291, 2008.

[17] F. Zohar, A., \& Nemet, "Fostering students knowledge and argumentation skills through dilemmas in human genetics," $J$. Res. Sci. Teach., vol. 39, no. 1, pp. 36-62, 2002.

[18] R. Trent, "Fostering Students' Argumentation skill in Geoscience Education," J. Geosci. Educ., vol. 57, pp. 224-232, 2009.

[19] A. Rahma, "Pengaruh Model Pembelajaran Reciprocal Teaching Berbantuan LKS Terhadap Prestasi Belajar Siswa," Musamus J. Sci. Educ., vol. 1, pp. 53-59, 2019.

[20] Naniastuti. I, "Perbandingan Model Pembelajaran Think Talk Write dan Make a Match Terhadap Prestasi Belajar Kimia Siswa Kelas X1 SMA YPK Merauke," Musamus J. Sci. Educ., vol. 1, 2019. 